\title{
Pengaruh Kualitas Layanan Internal dan Kepuasan Kerja terhadap Kinerja Karyawan Hotel
}

\author{
Ni Luh Putu Surining Jati1, I Ketut Surata², I Gusti Agung Febrianto3* \\ 1,2,3 Program Studi Bisnis Hospitaliti, Politeknik Pariwisata Bali \\ Jl. Dharmawangsa, Kampial, Nusa Dua, Bali \\ 1suriningjati@yahoo.com, 2surata_iketut@yahoo.com, 3*igustiagung.febrianto@gmail.com \\ *Corresponding author
}

\begin{tabular}{l|l|l} 
Received: Mei, 2021 & Accepted: Mei, 2021 & Published: Juni, 2021
\end{tabular}

\begin{abstract}
This research was conducted to analyze the influence of internal service quality on job performance, analyze the influence of job satisfaction on job performance, and analyze the influence of internal service quality and job satisfaction on job performance at The RitzCarlton Bali. Questionnaires as the data collection technique were distributed to employees at The Ritz-Carlton Bali as the respondents. The total samples were 85 respondents which identified using simple random sampling technique and Slovin formula as sampling technique. The measurements of this research used a Likert scale. The methods of data analysis used were classic assumption testing, coefficient determination, hypothesis test, and testing by SPSS version 24. The results of data analysis indicated that internal service quality has a positive and significant effect on job performance at The Ritz-Carlton Bali as proven by the value of $t_{\text {count }}(3,259)>t_{\text {tabel }}(1,663)$. Job satisfaction has a positive and significant effect on job performance at The Ritz-Carlton Bali as proven by the value of $t_{\text {count }} 2,742>t_{\text {tabel }}$ $(1,663)$. and Internal service quality and job satisfaction simultaneously have a contributing is 5,21\% through to the job performance. While the other remaining $4,79 \%$ is influenced by the other variable studied in this research.
\end{abstract}

Keywords: service quality, job satisfaction, job performance

\begin{abstract}
Abstrak
Penelitian ini dilakukan dengan tujuan untuk menganalisis pengaruh kualitas layanan internal terhadap kinerja karyawan, mengkaji kepuasan kerja terhadap kinerja karyawan, dan menganalisis pengaruh kualitas layanan internal dan kepuasan kerja terhadap kinerja karyawan di The Ritz-Carlton Bali. Teknik pengumpulan data yang digunakan adalah dengan menyebar kuesioner kepada responden yang merupakan karyawan di The RitzCarlton Bali. Jumlah sampel yang ditetapkan adalah 85 responden dengan pengambilan sampel menggunakan teknik simple random sampling dan menggunaka rumus Slovin. Pengukuran dalam penelitian ini menggunakan skala Likert. Teknik analisis data yang digunakan adalah pengujian asumsi klasik, pengujian regresi linier berganda, pengujian koefisien determinasi, pengujian hipotesis, dan pengujian melalui SPSS versi 24. Berdasarkan hasil analisis data dapat diperoleh simpulan bahwa kualitas layanan internal secara parsial berpengaruh positif dan signifikan terhadap kinerja karyawan di The Ritz-Carlton Bali,
\end{abstract}


Pengaruh Kualitas Layanan Internal dan Kepuasan Kerja Terhadap Kinerja Karyawan Hotel

Ni Luh Putu Surining Jati, I Ketut Surata, I Gusti Agung Febrianto

seperti terlihat dari nilai $t_{\text {hitung }}(3,259)>t_{\text {tabel }}(1,663)$. Kepuasan kerja secara parsial berpengaruh positif dan signifikan terhadap kinerja karyawan di The Ritz-Carlton Bali, seperti terlihat dai nilai uji $t_{\text {hitung }}(2,742)>t_{\text {tabel }}(1,663)$. Kualitas layanan internal dan kepuasan kerja pada nilai Uji Koefisien Determinasi $\left(R^{2}\right)$ menunjukkan bahwa kualitas layanan internal dan kepuasan kerja secara simultan berkontribusi sebesar 5,21 terhadap kinerja karyawan, sedangkan sisanya sebesar 4,79\% dipengaruhi variabel lain.

Kata kunci: kualitas pelayanan, kepuasan kerja, kinerja karyawan

\section{PENDAHULUAN}

Sumber Daya Manusia dalam perusahaan mempunyai peranan yang sangat penting dalam memajukan perusahaan karena sumber daya manusia merupakan satu-satunya sumber daya yang memiliki akal perasaan, keinginan, keterampilan, dan pengetahuan. Kinerja yang baik adalah langkah menuju pencapaian tujuan organisasi. Oleh sebab itu, lebih banyak usaha yang diperlukan untuk meningkatkan kinerja karyawan. Alasannya karyawan memiliki kemampuan untuk mempengaruhi persepsi pembeli. Kinerja atau performa kerja karyawan yang baik dapat menjadi keistimewaan tersendiri bagi sebuah perusahaan.

Istilah kinerja karyawan didefinisikan sebagai hasil yang dicapai dari tindakan dengan dengan keterampilan karyawan yang tampil di beberapa situasi menurut Prasetya dan Kato (2011:91). Menurut Suhartini (2015:660) keungulan kinerja merupakan modal penting untuk mengantarkan organisasi mencapai tingkat keunggulan bersaing yang optimal dan efisien. Internal service quality merupakan kualitas layanan internal sebagai kualitas dari lingkungan kerja yang memberikan kontribusi terhadap kepuasan karyawan sehingga akan berpengaruh terhadap kinerja karyawan. The Ritz-Carlton Bali merupakan hotel bintang 5 yang terletak di Sawangan, Nusa Dua, Bali. Memberikan pelayanan yang berkualitas hotel ini selalu mengutamakan dan memperhatikan para karyawannya dengan memberikan pelatihan, pengawasan, serta pemberian standar operasional prosedur (SOP) berupa 6 Gold Standard yaitu Credo, The Employee promise, 3 steps of service, moto, service value, dan The Ritz-Carlton Mistique yang menjadi fondasi atau patokan bagi karyawan dalam memberikan pelayanan.

The Ritz-Carlton Bali memiliki 11 departemen di mana total karyawan pada tahun 2019 sebanyak 589 karyawan. Menurut Fornell, C. $(1992,12)$ kepuasan karyawan akan pelayanan internal yang berkualitas akan mendorong tumbuhnya loyalitas karyawan dalam organisasi, dan pada akhirnya akan mendorong penciptaan nilai pelayanan eksternal yang kemudian menentukan kepuasan pelanggan eksternal. Akan tetapi, berdasarkan data yang diperoleh dari Quality Departemen di The Ritz-Carlton Bali penilaian kinerja karyawan Hotel The Ritz-Carlton Bali didasarkan pada pemberian nilai dari konsumen melalui guestVoice. GuestVoice merupakan platform yang dimiliki oleh Marriott untuk mengumpulkan Guest Satisfaction survey. Namun berdasarkan hasil analisis kinerja karyawan di The Ritz-Carlton Bali cenderung tidak stabil dan mengalami peningkatan jumlah problem pada periode 2019. Hasil problem analysis menunjukkan adanya peningkatan sebesar $2.4 \%$ pada tahun 2019 dengan rata-rata masalah sebesar 25.08. Kurangnya pengetahuan dapat dikoreksi dengan kepemimpinan yang lebih efektif maka standar yang perlu diterapkan adalah standar zero defect. Industri jasa dalam hal ini hotel, mengutamakan nol kesalahan dalam pelayanan. Apabila terdapat kesalahan sedikitpun dalam industri hotel akan mendapatkan dampak yang begitu besar.

Mangkunegara (2011:118) berpendapat bahwa salah satu indikasi dari menurunnya tingkat kepuasan kerja adalah tingginya tingkat absensi, keterlambatan karyawan, tinggi keluar masuk karyawan, menurunnya produktivitas kerja dan prestasi kerja karyawan. Berdasarkan data late attendance karyawan diketahui bahwa adanya peningkatan sebesar 
9.15\% dengan rata-rata 3.78 pada tahun 2019. Sedangkan rata-rata toleransi yang telah ditetapkan oleh hotel sebesar 2\%. Hal ini berarti karyawan telah melampaui batas toleransi. Hal tersebut menunjukkan bahwa kinerja karyawan The Ritz-Carlton Bali masih kurang dan tidak sesuai dengan ekspektasi pimpinan. Fenomena ini menunjukkan bahwa kualitas layanan internal dan kepuasan kerja The Ritz-Carlton Bali sangat penting untuk meningkatkan kinerja karyawan karena faktor kualitas layanan internal dan kepuasan kerja dapat mendorong seseorang untuk menjadi yang terbaik. Tetapi hal tersebut belum mampu meningkatkan kinerja karyawan sebagaimana yang diharapkan oleh pihak manajemen. Rendahnya kinerja karyawan dapat berdampak pada kualitas pelayanan yang menjadikan image perusahaan menjadi buruk. Oleh karena itu, untuk mengetahui pengaruh kualitas layanan internal dan kepuasan kerja terhadap kinerja karyawan, perlu dilakukan penelitian lanjut. Marina Laksarin Azic (2017) menjelaskan bahwa pentingnya kepuasan dengan hubungan manjemen dan rekan kerja dan berpengaruh pada kepuasan kerja dan hospitality secara keseluruhan. Untuk mendapatkan keunggulan kompetitif pengembangan kualitas pelayanan merupakan hal yang sangat penting bagi perusahaan selain menjadi kode akses penting dari industri perhotelan, kualitas pelayanan juga menjadi bottom line bagi perusahaan (Mohamad dkk., 2017). Tujuan penelitian ini untuk menganalisis pengaruh kualitas layanan internal terhadap kinerja karyawan, mengkaji kepuasan kerja terhadap kinerja karyawan, dan menganalisis pengaruh kualitas layanan internal dan kepuasan kerja terhadap kinerja karyawan di The Ritz-Carlton Bali.

\section{KAJIAN PUSTAKA}

Menurut Heskett (1994) kualitas layanan internal merupakan kualitas dari lingkungan kerja yang memberikan kontribusi terhadap kepuasan karyawan. Heskett (1994) mencatat bahwa internal service quality melibatkan pengukuran dari workplace dan content, rekrutmen, pengembangan, rewards, recognition, dari karyawan. Berdasarkan penjelasan tersebut dapat disimpulkan bahwa pada dasarnya sebuah organisasi menghadapi dua customer sekaligus, yakni secara internal yaitu karyawan dan eksternal yaitu pelanggan. Jika organisasi ingin memberi layanan yang unggul terhadap customer, maka peningkatan kualitas layanan harus dilakukan baik secara internal (internal service quality) maupun secara eksternal (external service quality). Peningkatan kualitas layanan secara internal akan berdampak pada kepuasan kerja (job satisfaction) para karyawan, selanjutnya kepuasan kerja ini akan mempengaruhi kualitas layanan eksternal kepada pelanggan. Menurut Zheithaml (1991) terdapat beberapa unsur yang mendukung kualitas layanan internal yang juga diteliti dalam studi ini yaitu: (1) Kesesuaian terhadap pekerjaan; (2) Kesesuaian terhadap teknologi; (3) Sistem pengawasan dan pengontrolan. Menurut Ananda dan Devesh (2016:335) "Service quality is psychological 'experience' of the customers in comparison with their 'expectation'”. Dapat dijelaskan bahwa kualitas pelayanan merupakan pengalaman psikologis pelanggan yang dibandingkan dengan harapan mereka.

Robbins (2015:170) menyebutkan bahwa kepuasan kerja adalah suatu sikap umum terhadap pekerjaan seseorang sebagai perbedaan antara banyaknya ganjaran yang diterima pekerja dengan banyaknya ganjaran yang diyakini seharusnya diterima. Berdasarkan pendapat Robbins, dapat diartikan bahwa kepuasan kerja adalah sikap dan perasaan karyawan terhadap pekerjaan yang dilakukannya, lingkungan kerja, ganjaran atau imbalan yang diterima nya dan penilaian terhadap hasil pekerjaannya, dimana perasaan tersebut dapat berupa senang, tidak senang, nyaman, dan tidak nyaman. Terdapat 5 indikator kepuasan kerja menurut Luthans (2008), antara lain: (1) Upah; (2) Peluang promosi; (3) Rekan kerja; (4) Pengawasan; (5) Pekerjaan itu sendiri.

Menurut Ricardianto (2018), kinerja adalah suatu gambaran tentang tingkat capaian pelaksanaan suatu program kegiatan atau kebijakan untuk mewujudkan target sasaran 
yang meliputi tujuan visi dan misi organisasi tersebut yang diatur dalam rencana strategis suatu organisasi. Dari pendapat Prasadja Ricardianto dapat disimpulkan bahwa kinerja merupakan hasil kerja yang dicapai oleh seorang karyawan sesuai dengan pekerjaan yang diberikan kepadanya dalam waktu tertentu. Dimensi kerja menurut Dessler (2010:329) menyatakan ada enam kategori yang digunakan untuk mengukur tingkat kinerja karyawan secara individual, sebagai berikut: (1) Quality; (2) Job knowledge; (3) Reliability; (4) Availability; (5) Independence. Mishra \& Sachan dalam Nasution (2018:57) mengungkapkan bahwa salah satu faktor pengaruh kinerja karyawan dalam suatu perusahaan adalah pengembangan karir di perusahaan. Menurut Mangkunegara (2012:9) kinerja adalah hasil dari kualitas dan jumlah pekerjaan yang dilakukan oleh seorang karyawan dalam menjalankan tugasnya sesuai dengan tanggung jawab yang diberikan.

\section{METODE PENELITIAN}

Penelitian ini memiliki dua variabel independen yang akan diukur pengaruhnya terhadap variabel dependen. Dua variabel independen tersebut adalah kualitas layanan internal dan kepuasan kerja. Sedangkan variabel dependen dalam penelitian ini yaitu kinerja karyawan. Penelitian ini bertujuan untuk menganalisis pengaruh pengaruh kualitas layanan internal dan kepuasan kerja terhadap kinerja karyawan di The Ritz-Carlton, Bali merupakan proses penyaringan data yang berulang atau kumpulan data yang sama dalam sebuah database.

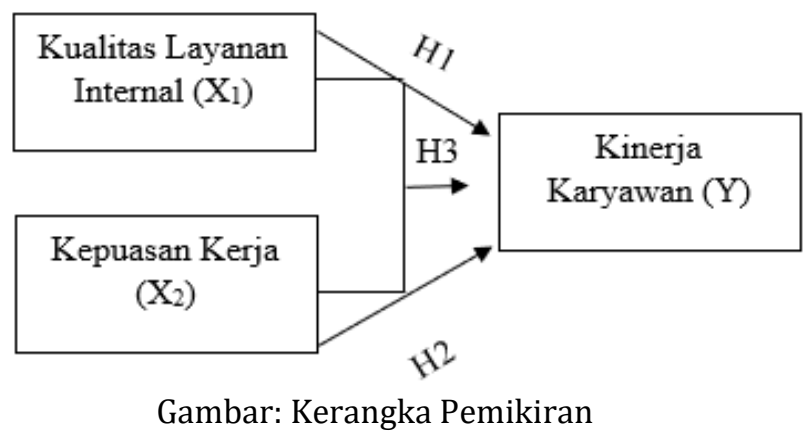

Berdasarkan kerangka pemikiran pada Gambar 1, dapat ditarik hipotesis yang berkaitan dengan variabel-variabel penelitian, yaitu sebagai berikut:

$\mathrm{H}_{01}$ : Tidak terdapat pengaruh yang positif dan signifikan antara kualitas layanan internal terhadap kinerja karyawan di The Ritz-Carlton Bali.

$\mathrm{H}_{\mathrm{a} 1}$ : Terdapat pengaruh yang positif dan signifikan antara kualitas layanan internal terhadap kinerja karyawan di The Ritz-Carlton Bali.

$\mathrm{H}_{02}$ : Tidak terdapat pengaruh yang positif dan signifikan antara kepuasan kerja terhadap kinerja karyawan di The Ritz-Carlton Bali.

$\mathrm{H}_{\mathrm{a} 2}$ : Terdapat pengaruh yang positif dan signifikan antara kepuasan kerja terhadap kinerja karyawan di The Ritz-Carlton Bali.

$\mathrm{H}_{03}$ : Tidak terdapat pengaruh yang positif dan signifikan antara kualitas layanan internal dan kepuasan kerja terhadap kinerja karyawan di The Ritz-Carlton Bali.

$\mathrm{H}_{\mathrm{a} 3}$ : Terdapat pengaruh yang negatif dan signifikan antara kualitas layanan internal dan kepuasan kerja terhadap kinerja karyawan di The Ritz-Carlton Bali.

Data dalam penelitian ini dikumpulkan dengan cara melakukan penyebaran kuesioner online melalui google form kepada 85 responden yang merupakan karyawan di The Ritz-Carlton Bali periode Maret-Mei 2020. Teknik analisis yang digunakan adalah uji validitas, uji reliabilitas, uji asumsi klasik (uji normalitas, uji multikolinearitas, dan uji heteroskedastisitas), analisis regresi linier berganda, uji t, uji F, koefisien determinasi dan sumbangan efektif dengan menggunakan program statistika SPSS for Windows version 24.0. Instrumen dalam penelitian ini menggunakan kuesioner. Kuesioner yang disebar 
merupakan instrumen penelitian yang mengukur variable penelitian, yakni faktor demografi yang terdiri dari variabel jenis kelamin, usia, pendidikan, dan masa kerja terakhir. Faktor demografi memiliki data dengan skala pengukuran nominal sehingga dalam setiap variabelnya memiliki pilihan jenjang yang telah disesuaikan. Uraiannya yakni: jenis kelamin, usia, pendidikan, masa kerja.

Pengujian instrumen penelitian dilakukan dengan uji validitas dan uji reliabilitas. Hasil dari uji validitas menyatakan keseluruhan item pernyataan mengenai kualitas layanan internal, kepuasan kerja, dan kinerja karyawan valid karena nilai $r_{\text {hitung }}>r_{\text {tabel }}$ $\left(\mathrm{r}_{\text {tabel }}=0,179\right)$. Hasil uji reliabilitas menyatakan bahwa item pernyataan dari variabel kualitas layanan internal, kepuasan kerja, dan kinerja karyawan lebih besar dari 0,60 sehingga, dapat disimpulkan bahwa butir atau item pertanyaan kuesioner yang digunakan sudah dinyatakan reliabel untuk digunakan di dalam pengambilan data penelitian.

\section{HASIL DAN PEMBAHASAN}

Dari hasil penelitian yang dilakukan kepada 85 karyawan di The Ritz-Carlton, Bali, dapat diketahui gambaran tentang karakteristik menurut jenis kelamin, umur, tingkat pendidikan, masa kerja. Karakteristik responden berdasarkan jenis kelamin yaitu responden perempuan lebih banyak dengan total 46 orang atau sebesar $45,9 \%$ sedangkan laki-laki sebanyak 39 orang Karakteristik responden berdasarkan usia yaitu rentang 2130 tahun paling banyak dengan jumlah 62 orang (72.8\%), diikuti dengan usia 31-40 tahun yaitu 14 orang $(16,5 \%)$ dan selanjutnya 41-50 tahun 6 orang (7.1), kemudian usia kurang dari 20 tahun $2(2,4 \%)$ dan yang terendah adalah usia lebih dari 50 tahun dengan jumlah 1 orang $(1.2 \%)$. Karakteristik responden berdasarkan tingkat pendidikan terakhir yaitu pendidikan terakhir SMA/SMK merupakan jumlah terbanyak yaitu 33 orang (38.8\%), diikuti oleh responden dengan pendidikan terakhir Sarjana berjumlah 31 orang (36,5\%), kemudian responden dengan pendidikan terakhir Diploma berjumlah 21 orang $(24,7 \%)$. Karakteristik responden berdasarkan masa kerja yaitu rentang masa kerja karyawan yang bekerja 1-3 tahun memiliki angka yang paling tinggi yaitu 42 orang $(49,4 \%)$, diikuti dengan kurang dari 1 tahun yaitu 30 orang (35,3\%), dan yang terendah adalah selama 4-6 yaitu sebanyak 13 orang $(15,3)$.

\subsection{Hasil Analisis}

Analisis Regresi Linier Berganda digunakan untuk mengetahui perubahan kinerja karyawan yang dipengaruhi oleh kualitas layanan internal dan kepuasan kerja. Hasil analisis regresi linier berganda dengan bantuan SPSS version 24 for Windows dapat dilihat pada Tabel 1.

Tabel 1: Hasil Analisis Regresi Linier Berganda

\begin{tabular}{|c|c|c|c|c|}
\hline & & Unstan & icients & $\begin{array}{l}\text { Standardized } \\
\text { Coefficients }\end{array}$ \\
\hline & & $B$ & Std. Error & Beta \\
\hline 1 & (Constant) & 0,915 & 0,266 & \\
\hline & Kualitas Layanan Internal & 0,398 & 0,122 & 0,413 \\
\hline & Kepuasan Kerja & 0,327 & 0,119 & 0,500 \\
\hline & endent Variable: Kinerja Ka & & & \\
\hline
\end{tabular}

Sumber: Data diolah menggunakan SPSS 24

Pada Tabel 1 dapat dilihat bahwa nilai kostanta sebesar 0,915, koefisien regresi kualitas layanan internal sebesar 0,398 dan koefisien regresi kepuasan kerja sebanyak 0,327 . Berdasarkan nilai kostanta dan nilai koefisien regresi masing-masing variabel bebas diperoleh persamaan regresi linier berganda sebagai berikut: 
Ni Luh Putu Surining Jati, I Ketut Surata, I Gusti Agung Febrianto

$\mathrm{Y}=0,915+0,398 \mathrm{X} 1+0,327 \mathrm{X} 2$

Berdasarkan perhitungan dengan rumus $\mathrm{Y}=\mathrm{a}+\mathrm{b} 1+\mathrm{b} 2$ diperoleh persamaan garis regresi linier berganda memberikan informasi bahwa:

1) Konstanta Nilai konstanta sebanyak 0,915 artinya jika variabel kualitas layanan internal dan kepuasan kerja ditiadakan maka kinerja karyawan bernilai sebanyak 0,915. Bila nilai variabel bebas (kualitas layanan internal dan Job Satisfaction) meningkat, maka variabel terikat (kinerja karyawan) akan mengalami peningkatan.

2) Kualitas Layanan Internal $\left(X_{1}\right)$ Nilai koefisien kualitas layanan internal $\left(X_{1}\right)$ sebesar 0,398 menunjukkan bahwa kinerja karyawan akan meningkat sebesar 0,398 poin apabila variabel kualitas layanan internal $\left(\mathrm{X}_{1}\right)$ mengalami kenaikan satu satuan. Koefisien kualitas layanan internal bernilai positif artinya kualitas layanan internal dan kinerja karyawan memiliki hubungan positif. Peningkatan kualitas layanan internal akan mengakibatkan peningkatan kinerja karyawan.

3) Kepuasan Kerja $\left(X_{2}\right)$ Nilai koefisien regresi variable kepuasan kerja terhadap kinerja karyawan sebanyak 0,327 artinya jika kinerja karyawan mengalami kenaikan sebesar satu satuan, sementara variabel lainnya tetap maka kinerja karyawan akan mengalami peningkatan sebesar 0,327. Koefisien kepuasan kerja bernilai positif artinya antara kepuasan kerja dan kinerja karyawan memiliki hubungan positif. Kenaikan kepuasan kerja akan mengakibatkan kenaikan pada kinerja karyawan.

Teknik analisis data yang digunakan untuk menguji hipotesis satu sampai tiga adalah uji $t$, uji F, koefisien determinasi dan sumbangan efektif.

1) Kualitas layanan internal terhadap kinerja karyawan hotel

Hasil pengujian hipotesis yang pertama diperoleh hasil penolakan $\mathrm{H}_{0}$, yang menyatakan bahwa kualitas layanan internal berpengaruh positif dan signifikan terhadap kinerja karyawan (nilai $t_{\text {hitung }}>t_{\text {tabel }}=3,259>1,663$; dan nilai signifikansi $<\propto=0,002<$ $0,1)$.

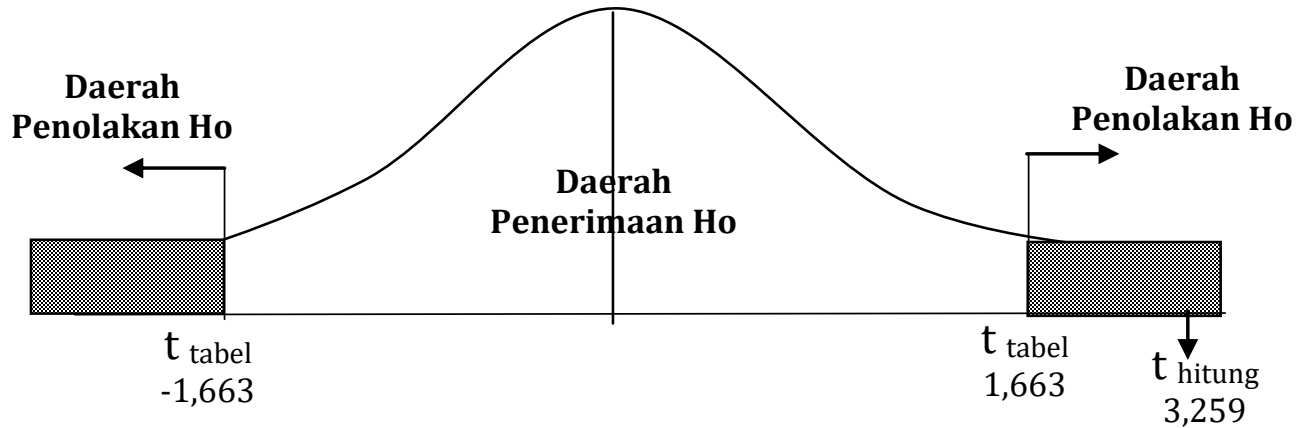

Gambar 2: Kurva Distribusi Uji t Pengujian Koefisien Kualitas Layanan Internal $\left(\mathrm{X}_{1}\right)$ terhadap Kinerja Karyawan (Y)

2) Kepuasan kerja terhadap kinerja karyawan hotel

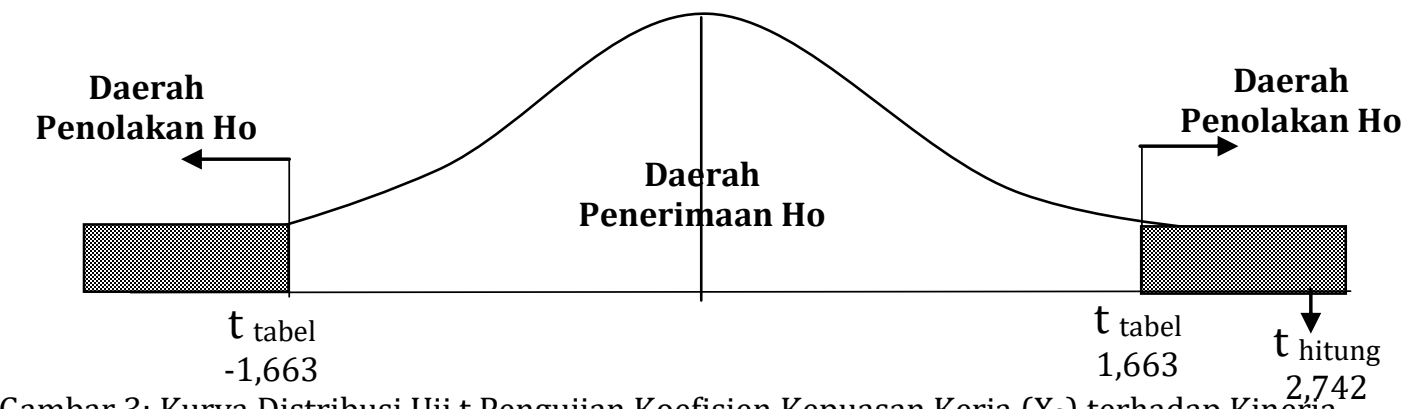

Gambar 3: Kurva Distribusi Uji t Pengujian Koefisien Kepuasan Kerja $\left(\mathrm{X}_{2}\right)$ terhadap Kinerja

Karyawan (Y) 
Ni Luh Putu Surining Jati, I Ketut Surata, I Gusti Agung Febrianto

Hasil pengujian hipotesis yang kedua diperoleh hasil penolakan $\mathrm{H}_{0}$, yang menyatakan bahwa kepuasan kerja berpengaruh positif dan signifikan terhadap minat beli (nilai $t_{\text {hitung }}>t_{\text {tabel }}=2,742>1,663$; dan nilai signifikansi $<\propto=0,007<0,1$ ).

3) Kualitas layanan internal dan kepuasan kerja terhadap kinerja karyawan hotel

Hasil pengujian hipotesis yang ketiga diperoleh hasil penolakan $\mathrm{H}_{0}$, yang menyatakan bahwa kualitas layanan internal dan kepuasan kerja berpengaruh positif dan signifikan terhadap kinerja karyawan $\left(\mathrm{F}_{\text {hitung }}>\mathrm{F}_{\text {tabel }}=44,512>2,37\right.$ dan nilai signifikansi $<\propto=0,000$ $<0,1$ ). Nilai koefisien determinasi pada hasil ini adalah $52,1 \%$ berarti pengaruh kualias layanan internal $\left(\mathrm{X}_{1}\right)$ dan kepuasan kerja $\left(\mathrm{X}_{2}\right)$ secara simultan terhadap kinerja karyawan adalah sebesar $52,1 \%$, sedangkan sisanya sebesar $47,9 \%$ dipengaruhi oleh faktor lain yang tidak diteliti pada penelitian ini.

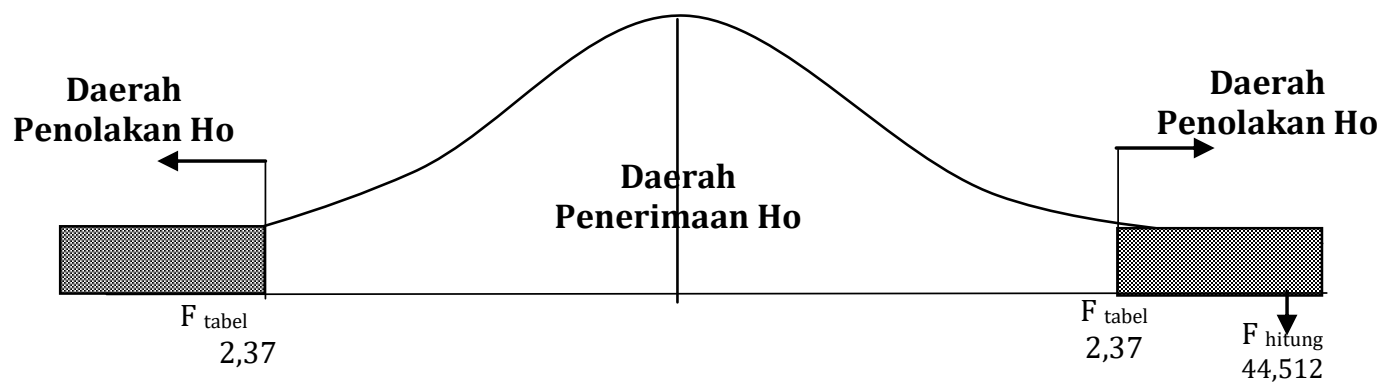

Gambar 4: Kurva Distribusi Uji F Pengujian Koefisien Kualitas Layanan Internal $\left(\mathrm{X}_{1}\right)$ dan Kepuasan Kerja $\left(\mathrm{X}_{2}\right)$ terhadap Kinerja Karyawan (Y)

Analisis koefisien determinasi bertujuan untuk mengetahui besarnya presentase variabel yang diteliti, yaitu variabel bebas kualitas layanan internal $\left(\mathrm{X}_{1}\right)$ dan kepuasan kerja $\left(\mathrm{X}_{2}\right)$ terhadap variabel terikat yaitu kinerja karyawan $(\mathrm{Y})$. Pada tabel 5.12 berikut ditampilkan hasil koefisien determinasi.

Tabel 2: Hasil Uji Koefisien Determinasi

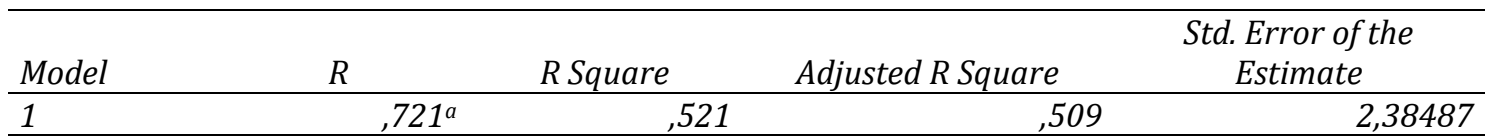

a. Predictors: (Constant), Kualitas Layanan Internal, Kepuasan Kerja

b. Dependent Variable: Kinerja Karyawan

Sumber: Data diolah menggunakan SPSS 24

Nilai R square yang diperoleh dari hasil analisis adalah 0,521 memiliki arti bahwa variabel bebas sebanyak 52,1\% (0,521 X 100\%), sisanya sebesar 47,9\% (100\% - 52,1\%) dijelaskan oleh variabel lain yang tidak digunakan dalam penelitian ini. Menurut teori Sugiyono (2012:184), jika interval koefisien determinasi berada diantara 40\% - 59,9\% maka koefisien determinasi tersebut dapat dikatakan sedang. Hasil koefisien determinasi dalam penelitian ini sebesar 52,1\% maka dapat dinyatakan bahwa kedua variabel bebas berpengaruh kuat terhadap variabel terikat.

Pengolahan data penelitian ini juga menghasilkan nilai sumbangan efektif dari masing-masing variabel bebas terhadap variabel terikat. Gunannya adalah untuk mengetahui seberapa besar pengaruh variabel kualitas layanan internal dan kepuasan kerja secara parsial terhadap kinerja karyawan. Hasilnya berupa presentase dan jika dijumlahkan akan sama hasilnya dengan koefisien determinasi atau $R$ square $\left(\mathrm{r}^{2}\right)$. Untuk memperoleh hasil ini diperlukan hasil analisis korelasi dan analisis linier yang diringkas dalam Tabel 5.13 di bawah ini. 
Pengaruh Kualitas Layanan Internal dan Kepuasan Kerja Terhadap Kinerja Karyawan Hotel

Ni Luh Putu Surining Jati, I Ketut Surata, I Gusti Agung Febrianto

Tabel 3: Hasil Analisis Korelasi Koefisien dan Regresi Beta Sumber: Data Primer, 2020 (diolah)

\begin{tabular}{cccc}
\hline Variabel & Correlations & $\begin{array}{c}\text { Standardized } \\
\text { Coefficients Beta }\end{array}$ & R square $\left(\mathrm{r}^{2}\right)$ \\
\hline Kualitas Layanan Internal & 0,690 & 0,413 & 0,521 \\
$\left(\mathrm{X}_{1}\right)$ & 0,677 & 0,348 & \\
Kepuasan Kerja $\left(\mathrm{X}_{2}\right)$ &
\end{tabular}

Berdasarkan Tabel 3 dapat dihitung kontribusi setiap variabel bebas menggunakan rumus sebagai berikut;

$$
\mathrm{SE}(\mathrm{X})=\mathrm{B}_{\mathrm{X}} \mathrm{X} \operatorname{rxy} \mathrm{X} 100 \%
$$

a. Sumbangan efektif kualitas layanan internal $\left(\mathrm{X}_{1}\right)$ terhadap kinerja karyawan $(\mathrm{Y})$ $\mathrm{SE}(\mathrm{X} 1) \%=\operatorname{BetaX} 1 \times \mathrm{r}_{\mathrm{x} 1 \mathrm{y}} \times 100 \%$ $\mathrm{SE}(\mathrm{X} 1) \%=0,413 \times 0,690 \times 100 \%$ $\mathrm{SE}(\mathrm{X} 1) \%=28,5 \%$

b. Sumbangan efektif kepuasan kerja $\left(\mathrm{X}_{2}\right)$ terhadap kinerja karyawan $(\mathrm{Y})$

$\mathrm{SE}(\mathrm{X} 1) \%=$ BetaX1 $\mathrm{x} \mathrm{r}_{\mathrm{x} 2 \mathrm{y}} \times 100 \%$

$\mathrm{SE}(\mathrm{X} 1) \%=0,348 \times 0,677 \times 100 \%$

$\mathrm{SE}(\mathrm{X} 1) \%=23,6 \%$

\subsection{Pembahasan}

Kualitas layanan internal berpengaruh positif signifikan terhadap kinerja karyawan di The Ritz-Carlton Bali. Pada hipotesis ini diperoleh hasil bahwa $\mathrm{H}_{01}$ ditolak karena nilai thitung bernilai 3,259 lebih besar dari ttabel 1,663 dan 0,002<0,1. Hasil penelitian ini selaras didukung dengan karakteristik responden yang memiliki masa kerja $>1$ tahun, yaitu sebanyak 42 orang dengan masa kerja 1-3 tahun dan sebanyak 13 orang dengan masa kerja 4-6 tahun. Dengan masa kerja diats 1 tahun cenderung sudah memahami standar operasional prosedur. Karyawan yang sudah karyawan yang sudah memahami standar prosedur cenderung akan dapat mengetahui kualitas pelayanan yang baik sehingga karyawan dapat meningkatkan meningkatkan kinerja.

Kepuasan kerja berpengaruh positif dan signifikan terhadap kinerja karyawan. Hasil ini diperoleh penolakan $\mathrm{H}_{02}$ karena nilai thitung bernilai 2,742 lebih besar dari $t_{\text {tabel }}$ 1,663 dan $0,007<0,1$. Hasil penelitian selaras dengan kondisi empiris yang didukung dengan karakteristik responden yang memiliki masa kerja $>1$ tahun, yaitu sebanyak 62 orang. Rentang usia 21-30 tahun cenderung lebih cepat menyerah dan mengeluh sehingga apabila tidak mampu menciptakan budaya kerjasama antar individu didalam organisasi dan tidak memperhatikan karyawan maka akan dapat menyebabkan karyawan merasa kurang puas.

Berdasarkan analisis data yang telah dilakukan dengan menggunakan alat bantu IBM SPSS statistik 24 diperoleh hasil bahwa variabel kualitas layanan internal dan kepuasan kerja berpengaruh positif dan signifikan secara simultan terhadap kinerja karyawan dengan persamaan regresi linier berganda yaitu kinerja $Y=0,915+0,398 \mathrm{X} 1+$ 0,327 X2 artinya bahwa jika nilai variabel bebas (kualitas layanan internal dan kepuasan kerja) meningkat, maka variabel terikat (kinerja karyawan) akan mengalami peningkatan. Sedangkan dari hasil uji F secara simultan kualitas layanan internal dan kepuasan kerja berpengaruh positif dan signifikan terhadap kinerja karyawan dapat dilihat dari $\mathrm{F}_{\text {hitung }}>$ $\mathrm{F}_{\text {tabel }}=44,512>2,37$ dan nilai signifikansi $=0,00<0,1$. Dilihat dari hasil uji koefisien determinasi menunjukkan bahwa kualitas layanan internal dan kepuasan kerja secara bersama-sama berkontribusi sebesar 52,1\% terhadap kinerja karyawan. Hal ini perlu disadari bahwa kinerja karyawan tidak hanya dipengaruhi terhdapat du varibel tersebut melainkan ada faktor lain yang mampu mempengaruhi. Hasil ini didukung dengan 
karakteristik responden dengan masa kerja $>1$ tahun, yaitu sebanyak 42 orang dengan masa kerja 1-3 tahun dan sebanyak 13 orang dengan masa kerja 4-6 tahun. Dengan masa kerja di atas 1 tahun karyawan The Ritz-Carlton Bali sudah memahami standar operasional prosedur sehingga karyawan sudah mengetahui kualitas pelayanannya dengan baik dimana hal tersebut dapat mengacu terhadap kinerja karyawan dan memberikan pelayanan terbaik terhadap pelanggan ekternal.

\section{KESIMPULAN}

Adapun kesimpulan dalam penelitian ini adalah Kualitas layanan internal berpengaruh positif dan signifikan secara parsial terhadap kinerja karyawan. Kepuasan kerja berpengaruh positif dan signifikan secara parsial terhadap kinerja karyawan. Kualitas layanan internal dan kepuasan kerja secara simultan berpengaruh signifikan terhadap kinerja kayawan di The Ritz-Carlton Bali. Sedangkan dari hasil analisis regresi linier diperoleh persamaan regresi linier berganda kualitas layanan internal dan kepuasan kerja memiliki hubungan positif dengan kinerja karyawan dan apabila kualitas layanan internal dan kepuasan kerja mengalami peningkatan maka akan mengakibatkan meningkatnya kinerja karyawan. Berdasarkan hasil analisis koefisien determinasi kualitas layanan internal dan kepuasan kerja memiliki pengaruh sebesar $52,1 \%$ sedangkan sisanya $47,9 \%$ dipengaruhi oleh faktor lain.

Untuk pihak manajemen The Ritz-Carlton Bali, diharapkan perlu memperhatikan kualitas layanannya terhadap karyawan, khususnya dengan mengevaluasi dan memperbaiki dimensi kualitas layanan yang dirasa karyawannya tidak memuaskan. Karyawan lebih sering ingin di perhatikan oleh perusahaan dan ingin dipenuhi keinginannya sesuai dengan kontrak dan perjanjian yang telah ditetapkan sebelumnya. Oleh sebab itu, disarankan agar perusahaan lebih sering melakukan pertemuan dan mengevaluasi karyawan untuk selalu mengetahui perkembangan setiap karyawannya serta perlu memperhatikan kebutuhan karyawannya misalnya teknologi yang mendukung di lingkungan kerja karena faktor tersebut juga dapat mempengaruhi kepuasan karyawan di dalam organisasi. Untuk karyawan di The Ritz-Carlton Bali diharapkan mampu menanamkan konsistensi tinggi terhadap dirinya serta tanggung jawab yang kuat dalam menjalankan tugas mereka dan di harapkan juga kepada setiap kepala departemen untuk mendampingi dan membimbing karyawannya serta menjaga dan meningkatkan keterikatan kerja guna meningkatkan kinerja karyawan.

\section{DAFTAR PUSTAKA}

Ananda, S \& Devesh, S. (2016). Service Quality and Customer Satisfaction: A Studi Case in The Perception of Retail Banking Customer In Oman. 17th International Scientific Conference on Economic and Social Development, 20- 21 October 2016, Warsaw, Poland. Hal 333-344

Azic, Marina Laksarin (2017). The Impact of Employee Satisfaction on Hospitability Performance. Tourism and Hospitality Management, ( 23) 1, pp. 105-117, 2017.

Fornell, C. (1992). A National Customer Satisfaction Barometer: The Swedish Experience, Journal of Marketing, (56) 1: 6-21

Heskett, J. L., Jones, T. O., Loveman, G. W., Sasser, W. E., Jr., \& Schlesinger L. A. (1994). Putting the Service-Profit Chain to Work. Harvard Business Review, Vol. 72, Feb. pp. 164-174

Luthans, F. (2008). Organizational Behavior. McGraw-Hill Companies, Inc. New York

Mangkunegara, A. P. (2012). Manajemen Sumber Daya Manusia Perusahan. Bandung: PT. Remaja Rosdakarya.

Mangkunegara. (2011). Manajemen Sumber Daya Perusahaan. PT. Remaja Rosdakarya. Bandung 
Mohamad, H. A. D., Yazid, M. S., Khatibi, A., \& Azam, S. F. (2017). Service quality, customer satisfaction and customer loyalty of the hotel industry in United Arab Emirates (UAE): A measurement model. European Journal of Management and Marketing Studies.

Nasution, F.N. (2018). The Influence of Career Development and Organizational Culture on Employee Performance. International Journal of Scientific Research and Management (IJSRM), 6(1), pp.57 -65.

Parasuraman, A., Berry, Leonard L., \& Zeithaml, Valarie, A. (1991). Refinement and Reassessment of The SERVQUAL Scale. Journal of Retailing. (67) 4 (Winter), pp. 420450

Prasetya, A., \& Kato. M,. (2011). The Effect Of Financial And Non Financial Compensation To The Employee Performance. International Research Symposium In Service Management Yogyakarta

Ricardianto, P. (2018). Human Capital Management. Jakarta : Media

Robbins, S. (2015), Perilaku Organisasi. Penerbit Salemba Empat. Jakarta

Sugiyono. (2012). Metode Penelitian Kuantitatif Kualitatif dan R\&B. Bandung: Alfabeta

Suhartini, Y. (2015). Analisis kualitas layanan internal dan kepuasan kerja terhadap kinerja karyawan hotel. Jurnal Akuntansi dan Manajemen. Hal 660-673. https://journal.upy.ac.id. 